Brazilian Journal

of Chemical

ISSN 0104-6632

Printed in Brazil

Engineering

\title{
EFFECT OF ETHANOL ON THE DRYING CHARACTERISTICS AND ON THE COUMARIN YIELD OF DRIED GUACO LEAVES (Mikania laevigata SCHULTZ BIP. EX BAKER)
}

\author{
M. G. Silva ${ }^{1, *}$, R. M. S. Celeghini' and M. A. Silva ${ }^{3}$ \\ ${ }^{1}$ Center of Exact Sciences and Technology, Federal University of Pampa, UNIPAMPA, R. \\ Pedro Anunciação 111, 96570-000, Caçapava do Sul-RS, Brazil \\ ${ }^{2}$ School of Food Engineering, State University of Campinas, UNICAMP, R. Monteiro \\ Lobato 80, Cidade Universitária Zeferino Vaz, 13083-862, Campinas - SP, Brazil \\ ${ }^{3}$ School of Chemical Engineering, State University of Campinas, UNICAMP, Av. Albert \\ Einstein 500, Cidade Universitária Zeferino Vaz, 13083-852, Campinas - SP, Brazil
}

(Submitted: August 7, 2016; Revised: May 17, 2017; Accepted: June 8, 2017)

\begin{abstract}
Guaco is a common medicinal plant in Brazil used for the treatment of respiratory diseases. Coumarin serves as a chemical marker for quality control of products derived from guaco. In this study, the drying kinetics and coumarin yield of guaco leaves dried with and without treating the surface with ethanol were evaluated. The drying experiments were carried out in a forced convection tunnel at 50 and $60^{\circ} \mathrm{C}$ temperatures and air velocities of 0.42 and $0.84 \mathrm{~m} / \mathrm{s}$. The results show that the samples with ethanol experienced faster water evaporation during drying experiments, thereby reducing the drying time by up to $35 \%$, and also had higher yields of coumarin. Storage experiments and color analysis were also performed. Treatment of dried guaco leaves with ethanol resulted in color degradation, but increased shelf life by $20 \%$.
\end{abstract}

Keywords: Phytotherapeutic drugs; Medicinal plant; Drying kinetics; Guaco; Ethanol treatment.

\section{INTRODUCTION}

Medicinal plants have been used by mankind for a long time. It is undeniable that they are a source of phytochemicals for phytotherapeutic drugs as well as prototypes for discovery and or synthesis of new pharmaceutical compounds.

Mikania laevigata Schultz Bip. Ex Baker is a medicinal plant that is popularly known as "guaco" in Brazil. It is widely used in the treatment of respiratory diseases because of its expectorant and bronchodilatory properties. Coumarin, an active component found in guaco, is considered to be one of the main constituents responsible for its medicinal activity. It is also used as a chemical marker for ensuring quality control of products derived from guaco (Anvisa, 2005a; Ferreira and Oliveira, 2010; Rufatto et al., 2012). Drying of guaco is a preferred method for conserving the activity of its active ingredients and extending the shelf life to ensure a continuous supply to the phytotherapeutic industry. It involves drying the plant at physiological maturity to a level such that the plant can be stored

*Corresponding author. E-mail address: mateussilva@unipampa.edu.br 
for extended periods without significant loss in its medicinal properties (Lorenzi and Matos, 2002).

Conventional drying processes used for the preservation of guaco leaves may damage coumarin by either enzymatic or microbial action, given the long drying time and, consequently, lead to deterioration of its phytotherapeutic properties (Martinazzo et al., 2010; Radünz et al., 2012).

Retention of the active components in thermally processed medicinal plants is a challenge for the phytotherapeutic industry (Rayaguru and Routray, 2010). Therefore, developing new techniques for drying is necessary to minimize loss of therapeutic activity and ensure product quality.

Ethanol has been used in the drying process to improve some attributes of the dried material such as rehydration capacity and shrinkage (Funebo et al., 2002), color (Pang, 2006; Braga and Silva, 2010), aroma retention (Braga et al., 2009) and vitamin C retention (Santos and Silva, 2009).

Our group previously used ethanol for modifying the atmosphere in the drying process (Braga et al., 2009; Santos and Silva, 2009). We consistently observed that ethanol accelerated the drying process. In order to evaluate if this result was a surface effect, ethanol was brushed onto the surface of the fruits (Braga and Silva, 2010; Silva et al., 2012), and the decrease in the drying time was even higher. Accelerated drying by ethanol has been recognized as a Marangoni effect (Silva et al., 2012), that is, a mass transfer is caused by a surface tension gradient (Scriven and Sternling, 1960).

Considering the encouraging results obtained for drying fruits and the importance of shortening the drying time to minimize loss of coumarin content and, consequently, to improve the quality of the phytotherapeutic drugs, we studied the influence of ethanol on the drying characteristics and on the coumarin yield from guaco leaves dried with and without the surface treatment with ethanol.

\section{MATERIALS AND METHODS}

\section{Sample preparation}

Guaco used in this study was obtained from the experimental field of the Chemical, Biological and Agricultural Pluridisciplinary Research Center (CPQBA) at the University of Campinas. The branches were manually removed using plant scissors. The harvested material was sent to the laboratory for determination of moisture content, which was about $81 \pm 1.3 \%$ (wet basis).
For drying in the tunnel the leaves were cut into small squares measuring $5 \times 5 \mathrm{~mm}$ to allow adequate distribution of sample in the tunnel sample holder (diameter: $145 \mathrm{~mm}$; depth: $35 \mathrm{~mm}$ ) so as to form a thin layer (Figure 1). Mass was measured using an electronic scale with a sensitivity of $\pm 0.001 \mathrm{~g}$.

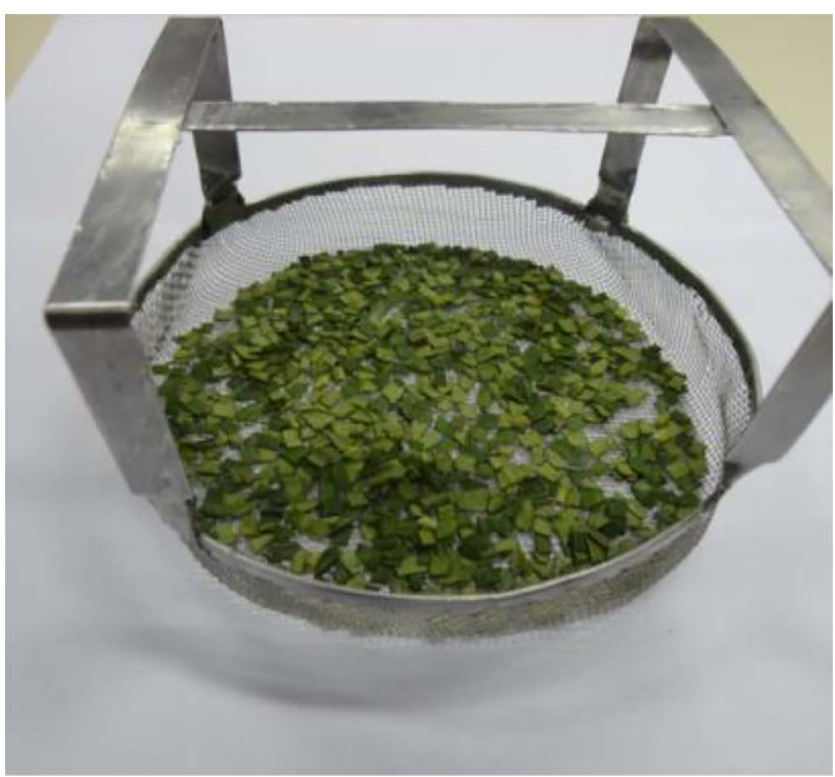

Figure 1. Even distribution of the cut leaves in the sample holder.

In the tests using absolute ethanol (99.5\%), it was necessary to develop a procedure to apply on the leaves. In the drying experiments conducted by Braga and Silva (2010) for pineapple, Correa et al. (2012) for banana and Silva et al. (2012) for apple, pineapple, and banana, ethanol was brushed on the fruit surface. We could not adopt the same procedure in our studies because of the fragile nature of guaco leaves. Therefore, cut samples were dipped in ethanol for $5 \mathrm{~s}$ at ambient temperature, just barely enough to ensure that the ethanol covered the entire leaf surface prior to drying experiments.

For drying in a forced convection oven, uncut guaco leaves were used because the purpose was to evaluate the influence of ethanol in a drying process similar to that carried out by the industry and farmers. The dipping process was the same as that described above.

\section{Drying experiments}

The tunnel dryer used in this study was composed of a blower, heater, gas flow equalizer, sample holder, electronic scale, a programmable logical controller and a data acquisition system that continuously recorded mass and temperature during the experiments as described by Morais and Silva (2004). 
The conditions used in the drying experiments are summarized in Table 1. Specific air temperatures were chosen because they provided the highest yields of coumarin in guaco leaves in previous drying studies (Radünz et al., 2012; Pereira et al., 2000). For velocity levels, the maximum air velocity supplied by the drying tunnel and half of its value were used for ease of the operational control. The samples were dried until they reached around $10 \%$ (wet basis) moisture content as recommended by the plant material pharmacopeia (Farias, 2004).

\begin{tabular}{lccc}
\multicolumn{4}{c}{ Table 1. Experimental conditions used for drying Mikania laevigata leaves. } \\
\hline Test & $\mathrm{T}\left({ }^{\circ} \mathrm{C}\right)$ & $\mathrm{V}(\mathrm{m} / \mathrm{s})$ & Ethanol \\
\hline 1 & 50 & 0.42 & Yes \\
2 & 60 & 0.42 & Yes \\
3 & 50 & 0.84 & Yes \\
4 & 60 & 0.84 & Yes \\
5 & 50 & 0.42 & No \\
6 & 60 & 0.42 & No \\
7 & 50 & 0.84 & No \\
8 & 60 & 0.84 & No \\
\hline
\end{tabular}

The experimental design presented in Table 1 was performed twice with leaves harvested in June and September, 2013.

The moisture ratio $(M R)$ of the samples was determined using equation (1).

$$
M R=\frac{M_{t}}{M_{0}}
$$

where $M_{0}$ is the initial moisture content and $M_{t}$ is the moisture content at time $t$.

\section{Coumarin determination}

Dried leaves were ground in a knife mill (IKA Labortechnik, model A10, Germany) for $10 \mathrm{~s}$ and separated in a Sonic Sifter (Advantech MFG, model L3P-26, USA) using Tyler sieves No. 40, 60, 80, 120, 170,230 for an average of $10 \mathrm{~min}$. Only the material retained from Tyler sieves No. 120 to Tyler 230 was used for coumarin extraction, adopting the method proposed by Celeghini et al. (2001). This method involves maceration in an ultrasound bath using absolute ethanol as the solvent.

The extracts were concentrated in a vacuum rotary evaporator (IKA, model RV10 Control, Brazil) at 60 ${ }^{\circ} \mathrm{C}$ and 175 mbar. The concentrated extract was diluted with acetonitrile (HPLC grade, J. T. Baker).

The coumarin content was determined by HPLC (Shimadzu, LC-10, Japan) coupled to a UV detector (Shimadzu, Photodiode array-SPD-M20A, Japan) and detected at a wavelength of $274 \mathrm{~nm}$. A SunFire C8 column $(75 \mathrm{~mm} \times 4.6 \mathrm{~mm} \times 3.5 \mu \mathrm{m})$ was used at $25^{\circ} \mathrm{C}$ with acetonitrile:Milli-Q water (40:60) as the mobile phase, and a flow rate of $1 \mathrm{~mL} / \mathrm{min}$ in isocratic mode with a sample volume of $20 \mu \mathrm{L}$. For quantitative analysis standard coumarin (1,2-benzopyrone, HPLC grade, Sigma) was run in HPLC and chromatograms compared with samples. All analyses were carried out in triplicate.

\section{Physical characterization of the dried samples}

The dried samples were subjected to color analysis and scanning electron microscopy (SEM).

Color analysis was carried out by means of a portable colorimeter (Hunter L, a, b, Miniscan, XE $45 / 0-\mathrm{L}$, USA), using the scale $L^{*}, a^{*}$ and $b^{*}$ of the CIELAB 1976 system using D65 illumination and a $10^{\circ}$ observation angle as a reference system. The chroma $\left(C^{*}\right)$ and hue $(h)$ were calculated from color parameters measured for the samples dried according to equations (2) and (3).

$$
\begin{gathered}
C^{*}=\sqrt{a^{2}+b^{2}} \\
h=\tan ^{-1} \frac{b^{*}}{a^{*}}
\end{gathered}
$$

where $a^{*}$ is related to redness and greenness, $b^{*}$ to yellowness and blueness, $h$ to tint angle $\left(0^{\circ}\right.$ to $\left.360^{\circ}\right)$, $C^{*}$ indicates saturation or intensity of color, and $L^{*}$ is related to lightness (Xiao et al., 2014). Analyses were performed in triplicate at different positions on the sample surface.

For SEM, dried samples were coated with a gold film by the Sputter Coater (POLARON, SC7620, United Kingdom) and observed by a scanning electron microscope (SEM/EDS, model LEO 440i, United Kingdom) with an accelerating voltage of $20 \mathrm{kV}$ and beam current of $100 \mathrm{pA}$ to obtain the micrographs.

\section{Storage experiments}

In order to verify the stability of the samples dried with and without ethanol, storage experiments were carried out following the conditions recommended by the Brazilian Health Surveillance Agency (Anvisa, $2005 \mathrm{~b}$ ). To provide the necessary amount of dried leaves for storage experiments, a forced convection oven at $50{ }^{\circ} \mathrm{C}$ and $0.1 \mathrm{~m} / \mathrm{s}$ was used to dry guaco leaves until they reached a moisture content of $10 \%$ (wet basis). 
Dried leaves of each sample (approx. $2.5 \mathrm{~g}$ ) were uniformly distributed in low-density $12 \times 12$ cm polyethylene bags (Talge, N6, Brazil) and were mechanically sealed. Twenty-four samples were prepared, 12 for storage in ambient conditions (normal atmosphere) and another 12 for storage in accelerated atmosphere, as presented in Table 2.

Table 2. Storage conditions for dried guaco leaves.

\begin{tabular}{lccccc}
\hline Conditions & $\begin{array}{c}\text { With } \\
\text { Ethanol }\end{array}$ & $\begin{array}{r}\text { Without } \\
\text { Ethanol }\end{array}$ & $\mathrm{T}\left({ }^{\circ} \mathrm{C}\right)$ & $\mathrm{RH}(\%)$ & Light \\
\hline NA* $^{*}$ & 6 & 6 & $23-27$ & $50-70$ & yes \\
AA** $^{*}$ & 6 & 6 & $40 \pm 2$ & $75 \pm 1$ & No \\
\hline
\end{tabular}

*Normal atmosphere (ambient conditions), **accelerated atmosphere.

The total study time was 6 months: from October, 2013, until April, 2014. At 30-day intervals, one sample from each drying and storage condition was collected for coumarin extraction.

\section{RESULTS AND DISCUSSION}

Following the experimental approach presented in Table 1, data were plotted to obtain a drying curve (Figure 2). By comparing the results with and without ethanol under the same conditions of temperature and air velocity, it is observed that ethanol accelerates the drying process and shortens the drying time. This intense water evaporation can be due to the Marangoni effect, as suggested by Silva et al. (2012) in pineapple.

All drying curves (Figure 2) are cumulative in that they comprise of total moisture, which includes water, other volatiles naturally present in the samples, and any additional ethanol. With respect to mass variation due to the use of ethanol on the surface of the leaves in some experiments, the mass transfer was found to be not only due to water evaporation from the sample, but also through vaporization of the ethanol or other volatile compounds from the leaves. In Figure 2-A, the superimposition of the drying kinetics curves for different air velocities if ethanol was used indicates that the effect of ethanol is more prominent than air velocity, at least in the range used in this study. On the other hand, for higher temperature (Figure 2-B), it is possible to notice the air velocity effect.

In Figure 2-B, increasing air velocity without ethanol decreased the drying time in all experiments. In ethanol experiments, this change occurred only at $50{ }^{\circ} \mathrm{C}$, because at $60{ }^{\circ} \mathrm{C}$ evaporation of the ethanol from the leaf surface is possible (test 4, Table 1) between dipping in ethanol and drying. A small amount of residual ethanol on the leaf surface may reduce evaporation of water.

In considering the drying kinetics, the difference between the moisture ratio of the experiments with and without ethanol, under the same conditions of temperature and air velocity, was higher at the beginning of the process. This indicates that the effect of ethanol is higher at the beginning of drying as there is greater availability of water. When comparing the experiments with and without ethanol, it was revealed that the highest reduction in drying time occurred in the experiments carried out at $0.42 \mathrm{~m} / \mathrm{s}$ at both $50{ }^{\circ} \mathrm{C}$ and $60{ }^{\circ} \mathrm{C}$ (in the order of $16 \%$ and $35 \%$, respectively).

To improve guaco leaves drying, treatment with ethanol should provide not only shorter drying times, but also aid in higher coumarin retention. Coumarin yield was determined for two sets of drying experiments, each one performed for leaves harvested at different periods of the year (June and September). The first set was carried out with leaves harvested in June 2013, since in the study conducted by Pereira et al. (2000) the highest coumarin content was found for leaves harvested in this month. In order to evaluate the difference in the coumarin yield of the leaves after the drying experiments, statistical analysis was carried out by Student's t-test with $95 \%$ confidence interval, as shown in Figure 3.

The mean coumarin yields of the leaves treated with ethanol were significantly different from the leaves without treatment under the same conditions of temperature and air velocity. For all tests, the coumarin yield was always higher if leaves were treated with ethanol before drying. In other words, the shorter the drying time, the higher the coumarin yield.

Other studies of guaco drying (Radünz et al., 2012; Pereira et al., 2012) also confirmed that higher values of coumarin content are obtained for shorter drying times. These authors believed that longer drying times could allow enzymatic and microbial actions responsible for alteration of the chemical composition of the plant tissue.

In order to analyze the influence of the variables on the coumarin content, the data was statistically analyzed to understand the effect of each variable. A Pareto chart is presented in Figure 4, in which the coumarin yield is the response (dependent variable). The vertical line indicates the confidence limit at $95 \%$, that is, the variables on the right side of the line are statistically significant at this level of confidence. Harvest period is the most influential variable on the coumarin yield, although it was not the objective of this study to evaluate it. Ethanol seems to be the 


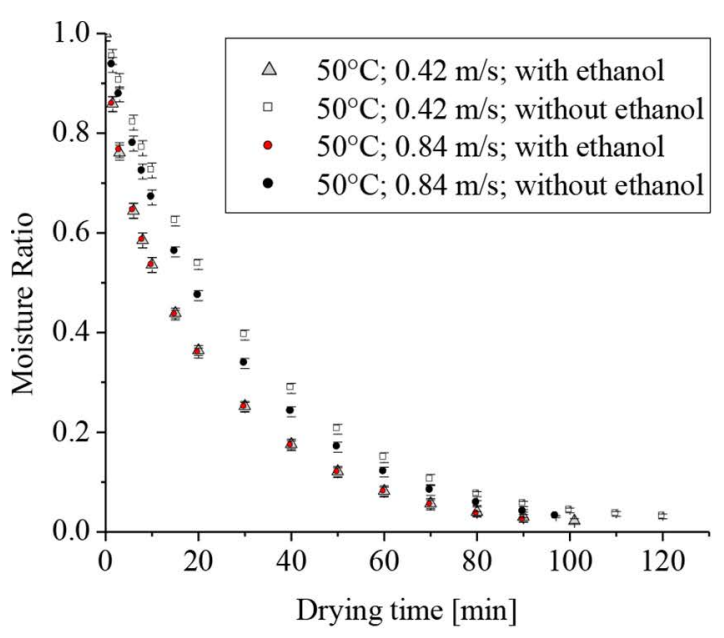

(A)

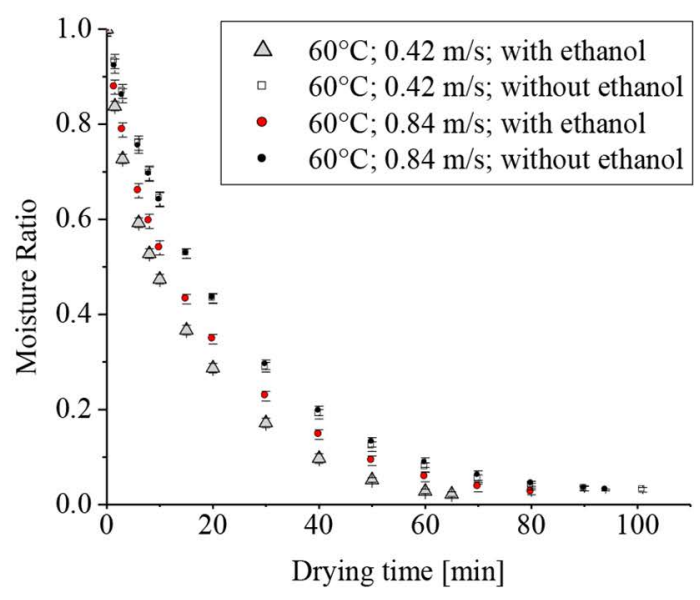

(B)

Figure 2. Drying curves of Mikania laevigata leaves with and without ethanol, at $0.84 \mathrm{~m} / \mathrm{s}$ and $0.42 \mathrm{~m} / \mathrm{s}$, at $50^{\circ} \mathrm{C}(\mathrm{A})$ and $60^{\circ} \mathrm{C}(\mathrm{B})$.

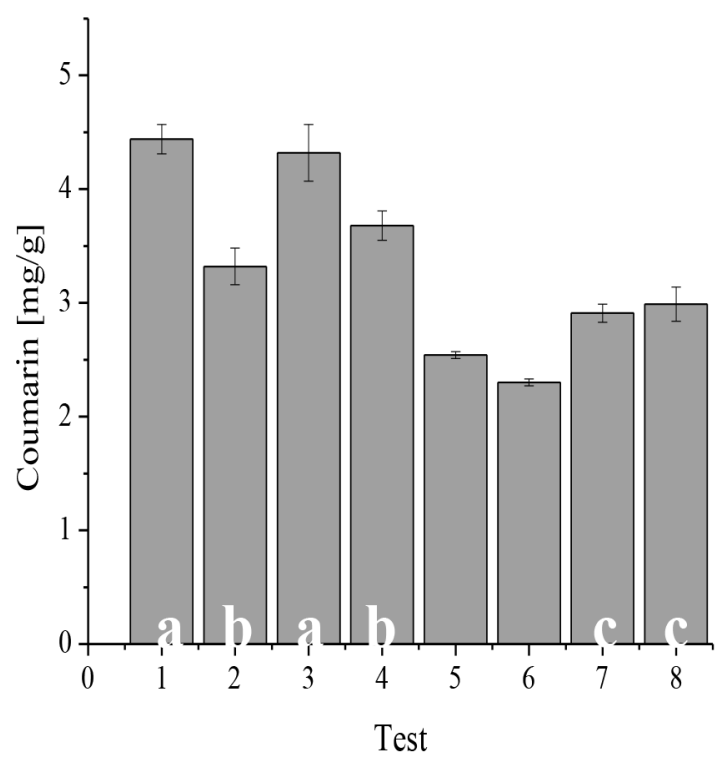

(A)

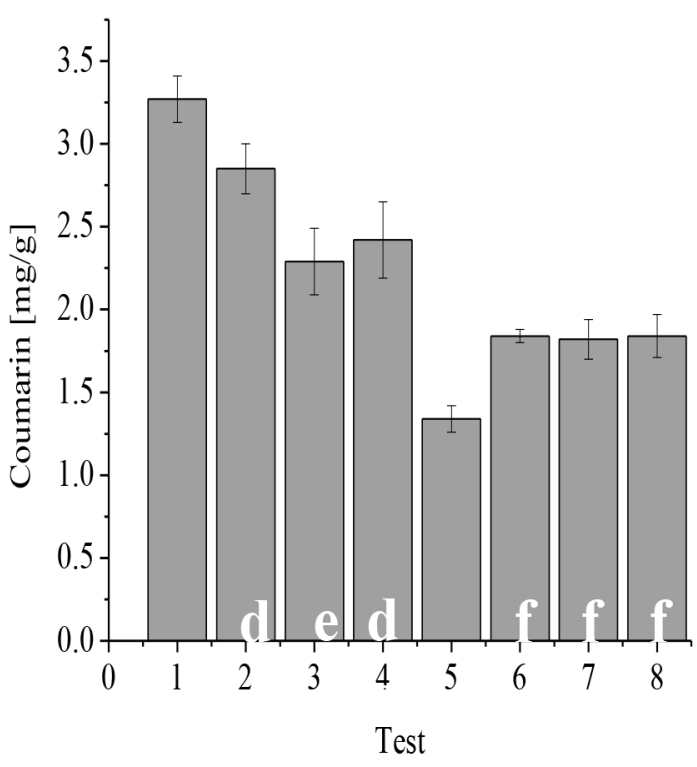

(B)

Figure 3. Coumarin yield of guaco leaves after drying in a tunnel, harvested in June, 2013 (A), harvested in September, 2013 (B). Coumarin yield (from the same harvest) followed by the same letter does not differ significantly $(\mathrm{p}<0.05)$.

second-most important variable (positive effect) and temperature (negative effect) is the third-most important variable. The negative effect of temperature on coumarin yield indicates that drying at $60{ }^{\circ} \mathrm{C}$ can cause thermal degradation of the coumarin molecule. With respect to air velocity, no significant effect was observed, but it contributed to interactions that significantly affected coumarin yield.

Color analysis (Table 3) showed that samples treated with ethanol presented less lightness $\left(L^{*}\right)$ as well as less saturation $\left(C^{*}\right)$ than the untreated ones, and presented a color orange-yellow (hue of $89^{\circ}$ ), while the untreated ones presented a color yellow-green (hue of $97^{\circ}$ ). It is know that chlorophyll is a component that confers green color to plant leaves (Walker et al., 2007; Padmanabhi and Deshmukh, 2017). Discoloration may therefore be due to the loss of chlorophyll during dipping of the cut samples in ethanol prior to drying, since this solvent is also used for chlorophyll extraction (Bozhkov and Borisova, 2003; Zhou et al., 2005). Interestingly, little color degradation was observed for samples of pineapple (Braga and Silva, 2010), banana 


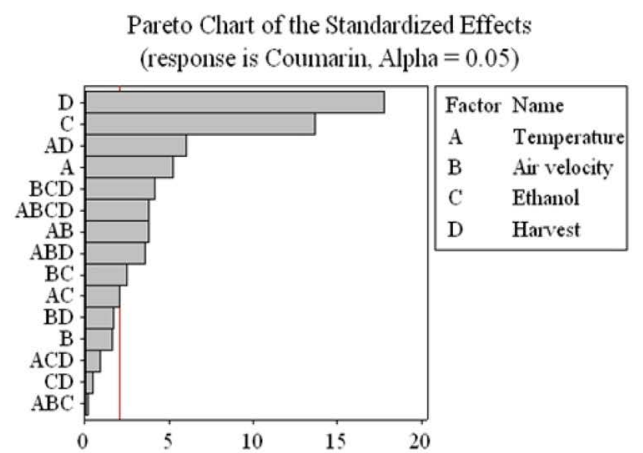

(A)

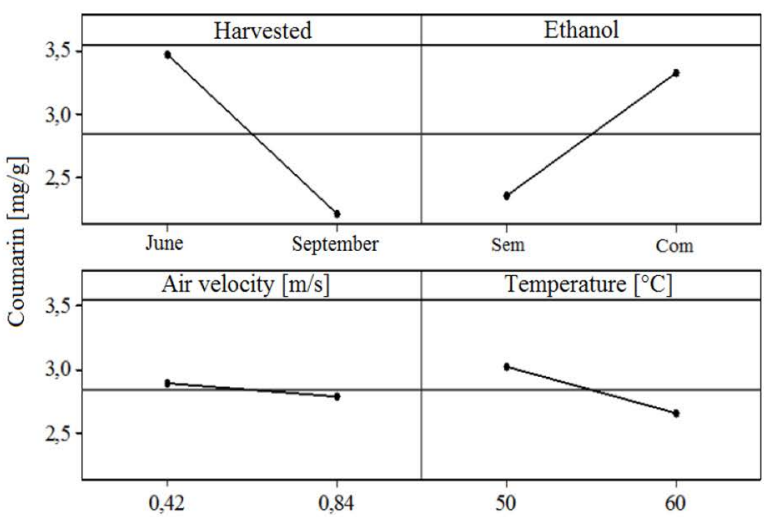

(B)

Figure 4. Pareto chart - Coumarin yield as response (A), effects of varying temperature, air velocity, and ethanol and harvest period on the coumarin yield (B).

(Correia et al., 2012) and wood (Pang, 2006) treated with ethanol. Depending on the pigments responsible for the color of the material, ethanol can have a positive or negative effect on color retention.

Table 3. Color analysis of Mikania laevigata leaves after drying in a tunnel.

\begin{tabular}{lccccc}
\hline Drying & \multicolumn{6}{c}{ Rectangular color space coordinates } & $\begin{array}{c}\text { Saturation } \\
\text { (Chroma) }\end{array}$ & Hue \\
\hline & $\boldsymbol{L}^{*}$ & $\boldsymbol{a}^{*}$ & $\boldsymbol{b}^{*}$ & $\boldsymbol{C}^{*}$ & $\boldsymbol{h}$ \\
\hline $\begin{array}{l}\text { With } \\
\text { ethanol }\end{array}$ & $25.26 \pm 0.01$ & $0.25 \pm 0.01$ & $15.66 \pm 0.09$ & 15.66 & $89^{\circ}$ \\
$\begin{array}{l}\text { Without } \\
\text { ethanol }\end{array}$ & $29.78 \pm 0.05$ & $2.03 \pm 0.06$ & $17.34 \pm 0.06$ & 17.46 & $97^{\circ}$ \\
\hline
\end{tabular}

*All values are significantly different $(\mathrm{p} \leq 0.05)$.
Figure 5 shows micrographs obtained by SEM in which it is possible to observe how intense were the shrinkage and deformation of samples treated with ethanol. In addition, as can be seen in Figures 5 (C) and (D) samples treated with ethanol had a rougher surface. These effects could be directly related to rapid water evaporation and consequently collapse of the pore structure. More intense shrinkage was also observed in pineapple samples treated with ethanol (Braga and Silva, 2010), although for banana (Correa et al., 2012) no significant effect of ethanol treatment was noticed.

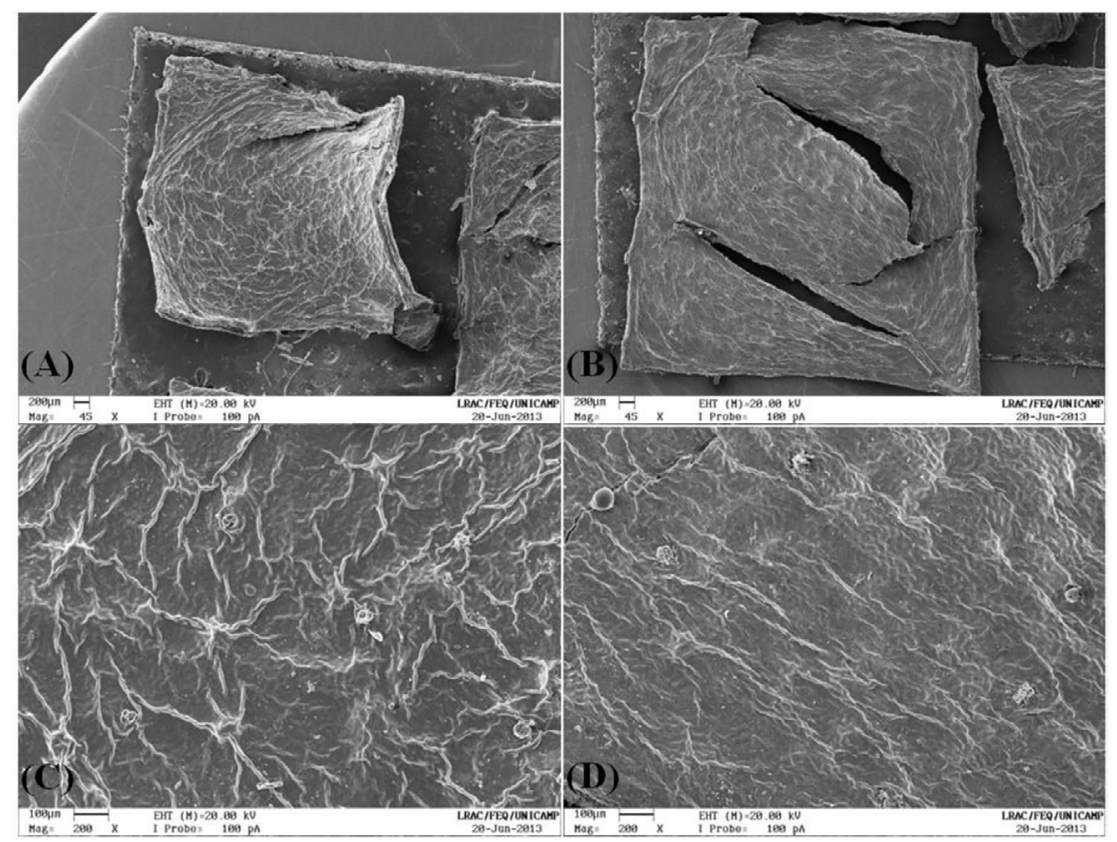

Figure 5. SEM micrographs of Mikania laevigata leaves after drying at $50{ }^{\circ} \mathrm{C}$ and $0.42 \mathrm{~m} / \mathrm{s}$, with ethanol (A) and (C); without ethanol (C) and (D). 
As farmers tend to dry guaco branches in ovens, we also performed an exploratory study by drying leaves and stems separately in a forced convection oven at 50 ${ }^{\circ} \mathrm{C}$ and $0.1 \mathrm{~m} / \mathrm{s}$. As expected, leaves dried faster than stems, with a drying time of 8.2 hours with ethanol treatment and 11.6 hours for untreated leaves, against 46.9 hours (treated) and 49.8 hours (untreated) for stems. The ethanol effect is more pronounced in leaves than in stems, probably because of the surface area available for ethanol contact, reinforcing the idea of a surface phenomenon at play. In addition, the coumarin content was much higher (approximately three times) in leaves than in stems.

The influence of storage time on coumarin content can be observed in Figure 6. Ethanol drying did not lead to a significant difference $(\mathrm{p}<0.05)$ from observations of plants stored in hostile conditions $\left(40{ }^{\circ} \mathrm{C}\right.$ and $\mathrm{RH}$ of $75 \%$ ). In such storage conditions, samples dried using ethanol pretreatment lost $80 \%$ of the coumarin content in 30 days and $97 \%$ in 180 days, while without ethanol pretreatment the loss was 72 and $98 \%$, respectively. On the other hand, the ethanol effect is clearly observed for samples stored in ambient conditions $\left(23-27^{\circ} \mathrm{C}\right.$ and RH of 50-70\%). After 180 days in ambient conditions, samples dried with and without ethanol pretreatment lost similar amounts of coumarin ( 82 and $84 \%$, respectively), in agreement with a previous study ( $81 \%$ in 150 days) (Rocha et al., 2008). Nevertheless, their storage time to reach the minimum amount of coumarin required to be considered a plant drug differed considerably, as shown in Table 4. The Brazilian Health Surveillance Agency (Anvisa) established $0.1 \%(1 \mathrm{mg} / \mathrm{g})$ as the minimum content of coumarin in dried guaco leaves (Anvisa, 2005a). Dried leaves pretreated with ethanol can be stored for $20 \%$ longer time than the untreated samples.

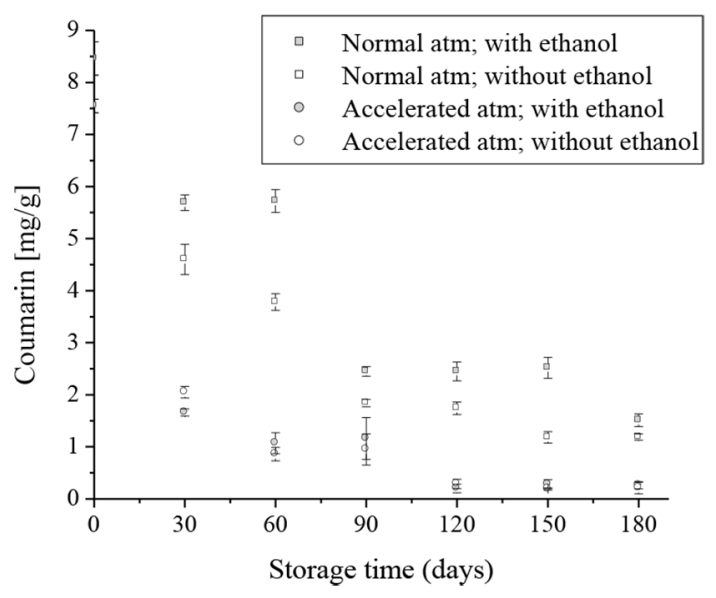

Figure 6. Coumarin yield during storage.
Table 4. Shelf life for guaco leaves stored in ambient conditions.

\begin{tabular}{lcccc}
\hline Samples & $\begin{array}{c}\text { Kinetics of } \\
\text { coumarin } \\
\text { depletion* }\end{array}$ & $\mathrm{k}(1 /$ days $)$ & $\mathrm{R}^{2}$ & $\begin{array}{c}\text { Shelf life } \\
\text { (days)** }\end{array}$ \\
\hline With ethanol & $\frac{d C_{\mathrm{C}_{6} \mathrm{O}_{2}}}{d t}=k \times C_{\mathrm{C}_{3} \mathrm{H}_{6} \mathrm{O}_{2}}$ & 0.0091 & 0.8983 & 993 \\
$\begin{array}{l}\text { Without } \\
\text { ethanol }\end{array}$ & $\frac{d C_{\mathrm{C}_{\mathrm{H}} \mathrm{O}_{2}}}{d t}=k \times C_{\mathrm{C}_{3} \mathrm{H}_{6} \mathrm{O}_{2}}$ & 0.0108 & 0.9402 & 826
\end{tabular}

*Zero, first and second order models were tested to ascertain the model that best describe the kinetics of coumarin depletion. The first order model presented the best fit $\left(\mathrm{R}^{2}\right)$ to the experimental data of Figure 6 .

**Time to reach the minimum amount of coumarin to be considered an herbal drug: $0.1 \%(1 \mathrm{mg} / \mathrm{g})$.

\section{CONCLUSIONS}

Dipping fresh guaco leaves in ethanol immediately prior to drying led to faster evaporation and consequently shorter drying times - a key factor reducing degradation of coumarin. Stability of coumarin in guaco is critical as it is a raw material for the phytotherapeutic industry and, therefore, must ensure consistent product quality.

Reduction in green color and shrinkage were more pronounced in samples pretreated with ethanol. However, such minor changes are not very important, since most consumers use coumarin extracts rather than directly using dried guaco leaves for treatment purposes.

The loss of coumarin over time was lower in the dried leaves pretreated with ethanol, resulting in a $20 \%$ increase in shelf life.

\section{NOMENCLATURE}

\author{
AA Accelerated atmosphere (-) \\ $a^{*} \quad$ Redness/greenness (-) \\ $b^{*} \quad$ Yellowness/blueness (-) \\ $C^{*} \quad$ Intensity of color (-) \\ $\mathrm{C}_{\mathrm{C}_{9} \mathrm{H}_{6} \mathrm{O}_{2}}$ Coumarin concentration $(\mathrm{mg} / \mathrm{g})$ \\ $\mathrm{h}$ Tint angle (-) \\ $\mathrm{L}^{*} \quad$ Lightness (-) \\ $M_{0} \quad$ Initial moisture content ( $\mathrm{kg}$ water $/ \mathrm{kg}$ dry matter) \\ $M R \quad$ Moisture ratio (-) \\ $M_{\mathrm{t}} \quad$ Moisture content at the instant ( $\mathrm{kg}$ water/kg dry matter) \\ NA Normal atmosphere (-) \\ RH Air relative humidity (\%) \\ $\mathrm{T} \quad$ Temperature $\left({ }^{\circ} \mathrm{C}\right)$ \\ $\mathrm{V} \quad$ Air velocity $(\mathrm{m} / \mathrm{s})$
}

\section{ACKNOWLEDGEMENTS}

The authors wish to acknowledge CAPES (Brazilian Agency for Improvement of Graduate Personnel, Brazil) for the MSc. Scholarship provided to M. G. Silva. 


\section{REFERENCES}

Anvisa. Agência Nacional de Vigilância Sanitária. Fascículo 6 da Parte II da 4 a Edição da Farmacopéia Brasileira. Resolução-RDC n. 313, de 25 de outubro de 2005. Diário Oficial da República Federativa da Brasil, Brasília, p. 23 (2005a).

Anvisa. Agência Nacional de Vigilância Sanitária. Guia para a realização de estudos de estabilidade. Resolução n. 1, de 24 de julho de 2005. Diário Oficial da República Federativa do Brasil, Brasília, ago. (2005b).

Bozhkov, O. D. and Borisova, L. V., Extraction and determination of trace amounts of Rhenium in plants. International Journal of Environmental \& Analytical Chemistry, 83(2), 135-141(2003).

Braga, A. M. P., Pedroso, M. P., Augusto, F. and Silva, M. A., Volatiles identification in pineapple submitted to drying in an ethanolic atmosphere. Drying Technology, 27(2), 248-257 (2009).

Braga, A. M. P. and Silva, M. A., Effect of ethanol on the drying kinetics and on the quality of pineapple slices. In Proceedings of the $17^{\text {th }}$ International Drying Symposium, Magdeburg, October 3-6, 1492-1497 (2010).

Celeghini, R. M. S., Vilegas, J. H. Y. and Lanças, F. M., Extraction and quantitative hplc analysis of coumarin in hydroalcoholic: extracts of Mikania glomerata sprengel. ("guaco") Leaves. Journal of the Brazilian Chemical Society, 12(6), 706-709 (2001).

Correa, J. L. G., Braga, A. M. P., Hochheim, M., and Silva, M. A., The influence of ethanol on the convective drying of unripe, ripe, and overripe bananas. Drying Technology, 30, 817-826 (2012).

Farias, M. R., Avaliação da qualidade de matériasprimas vegetais. In Farmacognosia: da planta ao medicamento; Simões, C. M. O. et al., Eds.; $5^{\text {th }}$ ed.; Editora UFRGS/ Editora UFSC: Porto Alegre/ Florianópolis, 263-288 (2004).

Ferreira, F. P. and Oliveira, D. C. R., New constituents from Mikania laevigata Shultz Bip. ex Baker. Tetrahedron Letters, 51(52), 6856-6859 (2010).

Funebo, T., Ahrné, L., Prothon, F., Kidman, S., Longton, M. and Skjöldebrand, C., Microwave and convective dehydration of ethanol treated and frozen apple - physical properties and drying kinetics. International Journal of Food Science and Technology, 37, 603-614 (2002).

Lorenzi, H. and Matos, F. J. A., Plantas medicinais no Brasil: nativas e exóticas cultivadas. Nova Odessa: Instituto Plantarum (2002).
Martinazzo, A. P., Melo, E. C., Corrêa, P. C. and Santos, R. H. S., Modelagem matemática e parâmetros qualitativos da secagem de folhas de capim-limão [Cymbopogon citratus (DC.) Stapf ]. Revista Brasileira de Plantas Medicinais, Botucatu, 12(4), 488-498 (2010).

Morais, M. M. and Silva, M. A., Preliminary study of pineapple aroma retention in drying with preloaded gas. In Proceedings of the $14^{\text {th }}$ International Drying Symposium, Sao Paulo, 1620-1627 (2004).

Padmanabhi, A. D. and Deshmukh, R. R., Hyperspectral Analysis of Soil Total Nitrogen using PLSR Method: A Review. International Journal of Theoretical and Applied Mechanics, 12(2), p. 357364 (2017).

Pang, S., Using methanol and ethanol vapours as drying media for producing bright color wood in drying of Radiata pine. In Proceedings of the $15^{\text {th }}$ International Drying Symposium, Budapest, Hungary, August 20-23, 1745-1749 (2006).

Pereira, A. M. S., Câmara, F. L. A., Celeghini, R. M. S., Vilegas, J. H. Y., Lanças, F. M. and França, S. V., Seasonal variation in coumarin content of Mikania glomerata. Journal of Herbs, Spices and Medicinal Plants, 7(2), 1-10 (2000).

Radünz, L. L., Melo, E. C., Barbosa, L. C. A., Rocha, R. P. and Berbert, P. A., Rendimento extrativo de cumarina de folhas de guaco (Mikania glomerata Sprengel) submetidas a diferentes temperaturas de secagem. Revista Brasileira de Plantas Medicinais, Botucatu, 14 (3), 453-457 (2012).

Rayaguru, K. and Routray, W., Effect of drying conditions on drying kinetics and quality of aromatic Pandanus amaryllifolius leaves. Journal of Food Science and Technology, 47 (6), 668-673 (2010).

Rocha, L., Lucio, E. M. A., França, H. S. and Sharapin, N., Mikania glomerata Spreng: desenvolvimento de um produto fitoterápico. Revista Brasileira de Farmacognosia, 18, 744-747 (2008).

Rufatto, L.C., Gower, A., Schwambach, J. and Moura, S., Genus Mikania: chemical composition and phytotherapeutical activity. Brazilian Journal of Pharmacognosy, 22 (6), 1384-1403 (2012).

Santos, P. H. S. and Silva, M. A., Kinetics of L-ascorbic acid degradation in pineapple drying under ethanolic atmosphere. Drying Technology, 27 (9), 947-954 (2009).

Scriven, L. E. and Sternling, C. V., The Marangoni effects. Nature. v. 187, p. 186-188 (1960). 
Silva, M. A., Braga, A. M. P. and Santos, P. H. S., Enhancement of fruit drying: the ethanol effect. In Proceedings of the $18^{\text {th }}$ International Drying Symposium, Xiamen, China, 11-15 (2012).

Walker, K. S., Bigelow, C. A. Smith, D. R. Van Scoyoc, G. E. and Reicher, Z. J., Aboveground responses of cool-season lawn species to nitrogen rates and application timings. Crop Science, 47(3), 1225-1236 (2007).
Xiao, H.W., Law, C.L., Sun, D.W., Gao, Z.J., Color change kinetics of American ginseng (Panax quinquefolium) slices during air impingement drying. Drying Technology, 32(4), 418-427 (2014).

Zhou, X., Carranco, R., Vitha, S., and Hall, T. C., The dark side of green fluorescent protein. New Phytologist, 168(2), 313-322 (2005). 
